Original Research Article

\title{
Intracervical foleys catheter: Can it serve as an alternative to standard pharmacological method of cervical ripening?
}

\author{
Bhaskar K. Murthy ${ }^{1}$, Mangala B. Murthy ${ }^{2 *}$, Rucha S. Teje ${ }^{1}$
}

${ }^{1}$ Department of Obstetrics and Gynaecology, ${ }^{2}$ Department of Pharmacology, Government Medical College, Miraj, Maharashtra, India

Received: 26 April 2017 Accepted: 24 May 2017

\section{*Correspondence to: Dr. Mangala B. Murthy, Email: mangala.bhaskar@ gmail.com}

Copyright: (C) the author(s), publisher and licensee Medip Academy. This is an openaccess article distributed under the terms of the Creative Commons Attribution NonCommercial License, which permits unrestricted noncommercial use, distribution, and reproduction in any medium, provided the original work is properly cited.

\begin{abstract}
Background: Ripening of cervix is a prerequisite for successful labour induction. Use of prostaglandins for this purpose incurs a high risk of uterine hyperstimulation and a relatively higher cost of treatment. intracervical Foleys catheter insertion is a mechanical method stated in literature. The present study was to compare the efficacy and safety and cost of intracervical Foleys catheter balloon insertion with intracervical dinoprostone application for preinduction cervical ripening in patients requiring labour induction at term.

Methods: This was a randomized, parallel group, active controlled study conducted in the obstetrics department of a tertiary care centre over a duration of one year. Group A received Dinoprostone cervical gel $0.5 \mathrm{mg}$ instilled in the cervical canal. Maximum of three doses (1.5mg dinoprostone) could be administered 6 hours apart. Patients randomized to group B were subjected to Foleys catheter insertion. Foleys catheter number 16 was used and balloon was inflated with $60 \mathrm{ml}$ of water. Primary efficacy parameter was change in Bishops score as compared to baseline and safety was monitored by comparing the total number of adverse events in the two groups.

Results: Total of 89 patients were enrolled into the study during one year period out of which 45 received dinoprostone gel and 44 received Foleys catheter insertion respectively. Change in Bishops score, mode of delivery and total number of maternal and foetal adverse events did not differ significantly between the two groups.

Conclusions: Efficacy and safety of Foleys catheter as a cervical ripening agent prior to induction of labour is comparable to dinoprostone gel. Since use of Foleys catheter is advantageous in terms of lack of specific storage conditions and cost of treatment, it could be considered a cost effective alternative for preinduction cervical ripening.
\end{abstract}

Keywords: Cervical ripening, Foleys catheter, Induction of labour, Prostaglandins

\section{INTRODUCTION}

In most pregnancies, process of labour starts spontaneously at term. However, in $15 \%$ of pregnant women, it needs to be artificially induced when continuation of pregnancy is perceived as a threat to either maternal or foetal well being. ${ }^{1}$ In such cases, the aim is to achieve a safe vaginal delivery by artificially inducing onset of labour. However, success of induction of labour is largely dependent on the state of the cervix. A soft and pliable cervix (ripe cervix) is more likely to give rise to successful induction as compared to a hard non-pliable cervix. (Unripe cervix). Thus ripening of cervix is a prerequisite for successful labour induction. ${ }^{2}$

In pregnant women with an unripe cervix, cervical ripening can be achieved by mechanical, surgical or pharmacological means. ${ }^{3,4}$ The commonest protocol for preinduction cervical ripening is intracervical instillation of a prostaglandin (PGE2- Dinoprostone gel). ${ }^{5}$ Despite being a commonly adopted procedure, prostaglandin gel has to be refrigerated for storage, it is contraindicated in 
patients of asthma and those allergic to prostaglandins, incur a high risk of uterine hyperstimulation and a relatively higher cost of treatment. ${ }^{6}$ As a result, the search for an ideal cervical ripening agent which is stable at room temperature as well as cost effective and can be safely used for most patients eludes. This prompts the exploration of other alternatives like mechanical methods of cervical ripening. In contrast to pharmacological means of cervical ripening, intracervical Foleys catheter insertion is a mechanical method stated in literature. Use of this method overcomes the above shortcomings of dinoprostone but has not been routinely used for the fear of failure of induction and risk of infection. Recently, results from a few large scale studies have shown Foleys catheter insertion more promising if aseptic precautions are undertaken. ${ }^{7,8}$ Thus, The purpose of the present study was to compare the efficacy and safety and cost of intracervical Foleys catheter balloon insertion with intracervical dinoprostone application for pre induction cervical ripening in patients requiring labour induction at term.

\section{METHODS}

This was a randomized, parallel group, active controlled study conducted in the obstetrics department of a tertiary care centre over a duration of one year. Study was approved by the institutional ethics committee and all the tenets of declaration of Helsinki were followed during the study. Study included patients at term with singleton gestation, cephalic presentation and an indication for induction of labour with an unripe cervix (defined as Bishop score less than or equal to 5). Study excluded patients with multiple pregnancies, scarred uterus, malpresentations, grand multiparas, premature rupture of membranes, ante partum haemorrhage and those with Bishop score more than 5.

Patients were enrolled into the study after obtaining a well informed written consent. Baseline data such as age, gravidity, parity, indication for induction and Bishop score at baseline were recorded and patients were randomized into one of the two groups. Randomization was done by computer generated random numbers. Patients randomized to Group A received Dinoprostone cervical gel. One prefilled syringe consisting of $0.5 \mathrm{mg}$ PGE2 was instilled in the cervical canal and patients were to remain in the supine position for 15 minutes after instillation. Maximum of three doses (1.5mg dinoprostone) could be administered 6 hours apart. Patients randomized to group B were subjected to Foleys catheter insertion. Foleys catheter number 16 was used and inserted into the cervical canal extra amniotically with aseptic precautions and balloon was inflated with $60 \mathrm{ml}$ of water. An adhesive tape was applied strapping the catheter to maternal thigh and patient was ambulated.

Primary efficacy parameter of the study was to assess the change in Bishops score which determined the extent of ripening of the cervix. Cervix was assessed for initial
Bishop score in both groups and change after 6 hours of last dose of dinoprostone or onset of contractions whichever was earlier in dinoprostone group and either after 6 hours or after expulsion of catheter, whichever was earlier in Foleys catheter group. Secondary efficacy parameters included mode of delivery, induction to delivery interval, failure of induction and need for oxytocin augmentation. Patients who failed to achieve bishop score of more than 5 after three doses of dinoprostone 6 hours apart or 12 hours of Foleys catheter insertion were labelled as treatment failure and were posted for caesarean section. Patients were objectively examined for any adverse events on temperature, blood pressure, foetal heart rate and uterine activity. Any subjective adverse effects reported by patient like pain, nausea, vomiting was also recorded. After delivery, foetal safety was assessed by 5 minute APGAR score and rate of admission to neonatal intensive care unit. Safety was assessed by comparing the total number of adverse events observed in the two groups. Mean cost of therapy incurred for cervical ripening in the two groups was calculated and depicted graphically.

Quantitative data like mean age, mean change in Bishop score, mean induction to delivery interval were analysed by t test. Qualitative data like maternal and foetal adverse events were analyzed by Fishers exact test. Chi square test was used to compare the mode of delivery.

\section{RESULTS}

Total of 89 patients were enrolled into the study during one year period out of which 45 received dinoprostone gel and 44 received Foleys catheter insertion respectively. Groups were comparable with respect to demographic and baseline characteristics like age, parity and indication for induction of labour (Table 1).

Both groups achieved cervical ripening with mean change in Bishops score being significantly higher than baseline. Mean change in Bishops score, albeit a little higher in the dinoprostone group as compared to Foleys catheter group, (7.2 vs 6.81) the difference between them was not statistically significant (Table 2).

Induction delivery interval was almost similar in the two groups (11.6 vs 11.1 in dinoprostone and Foleys catheter group respectively). Proportion of patients requiring additional oxytocin augmentation and caesarean section rate were apparently higher in the Foleys catheter group while failure of induction was apparently higher in dinoprostone group. These differences however were not statistically significant. (Table 3 ).

The total number of adverse events in both study groups for maternal and fetal safety parameters was not statistically different (Table 4 and 5). 
Table 1: Demographic and baseline parameters of the two study groups.

\begin{tabular}{|c|c|c|c|c|}
\hline Sr. no & Parameter & $\begin{array}{l}\text { Dinoprostone group } \\
(\mathrm{n}=\mathbf{4 5})\end{array}$ & $\begin{array}{l}\text { Foleys catheter group } \\
(n=44)\end{array}$ & $P$ value \\
\hline 1. & Mean age & 23.44 years & 23.06 years & 0.2820 \\
\hline \multirow{2}{*}{ 2. Parity } & Nullipara & $34(75.66 \%)$ & $32(72.72 \%)$ & \multirow{2}{*}{0.8489} \\
\hline & Multipara & $11(24.44 \%)$ & $12(27.27 \%)$ & \\
\hline \multirow{6}{*}{$\begin{array}{l}\text { 3. Indication for } \\
\text { induction }\end{array}$} & Postdate pregnancy & $29(64.44 \%)$ & $26(59.90 \%)$ & \multirow{6}{*}{0.0760} \\
\hline & PIH & $9(20 \%)$ & $6(13.63 \%)$ & \\
\hline & Oligohydramnios & $2(4.44 \%)$ & $11(25 \%)$ & \\
\hline & IUGR & $1(2.22 \%)$ & $0(0 \%)$ & \\
\hline & Uteroplacental insufficiency & $1(2.22 \%)$ & $0(0 \%)$ & \\
\hline & Decreased foetal movements & $3(6.66 \%)$ & $1(2.27 \%)$ & \\
\hline
\end{tabular}

Table 2: Comparison of Bishops scores in the two study groups.

\begin{tabular}{|llll|}
\hline $\begin{array}{l}\text { Bishops } \\
\text { score }\end{array}$ & $\begin{array}{l}\text { Dinoprostone } \\
\text { group }(\mathbf{n = 4 5})\end{array}$ & $\begin{array}{l}\text { Foleys } \\
\text { catheter } \\
\text { group }(\mathbf{n = 4 4 )}\end{array}$ & $\begin{array}{l}\mathbf{P} \\
\text { value }\end{array}$ \\
\hline $\begin{array}{l}\text { Mean pre- } \\
\text { induction } \\
\text { Bishops } \\
\text { score }\end{array}$ & 3.288 & 3.25 & 0.5238 \\
\hline $\begin{array}{l}\text { Mean post- } \\
\text { induction }\end{array}$ & 10.488 & 10.0681 & 0.1853 \\
$\begin{array}{l}\text { Bishops } \\
\text { score }\end{array}$ & & & \\
\hline $\begin{array}{l}\text { Mean } \\
\text { change in } \\
\text { Bishops } \\
\text { score from } \\
\text { baseline }\end{array}$ & 7.2 & 6.8181 & 0.2322 \\
\hline
\end{tabular}

Table 3: Comparison of secondary efficacy parameters in the study groups.

\begin{tabular}{|c|c|c|c|}
\hline $\begin{array}{l}\text { Secondary } \\
\text { efficacy } \\
\text { parameter }\end{array}$ & $\begin{array}{l}\text { Dinoprostone } \\
\text { group }(n=\mathbf{4 5})\end{array}$ & $\begin{array}{l}\text { Foleys } \\
\text { catheter } \\
\text { group } \\
(\mathrm{n}=44)\end{array}$ & $\begin{array}{l}\mathbf{P} \\
\text { value }\end{array}$ \\
\hline $\begin{array}{l}\text { Mean induction to } \\
\text { delivery interval }\end{array}$ & 11.6252 hours & $\begin{array}{l}11.1395 \\
\text { hours }\end{array}$ & 0.4593 \\
\hline $\begin{array}{l}\text { Proportion of } \\
\text { patients requiring } \\
\text { oxytocin } \\
\text { augmentation }\end{array}$ & $44 \%$ & $63 \%$ & 0.2026 \\
\hline $\begin{array}{l}\text { Mode of delivery: } \\
\text { Vaginal delivery } \\
\text { Caesarean section }\end{array}$ & $\begin{array}{l}20(44.44 \%) \\
25(55.55 \%)\end{array}$ & $\begin{array}{l}13(41 \%) \\
26(59 \%)\end{array}$ & 0.6355 \\
\hline $\begin{array}{l}\text { Patients with } \\
\text { failed induction }\end{array}$ & $2(4.44 \%)$ & $0(0 \%)$ & 0.4944 \\
\hline
\end{tabular}

All patients in Foleys catheter group required a single catheter and thus the mean cost of therapy in this group was rupees 55 amounting to the cost of one piece. On the contrary, out of 45 patients in the dinoprostone group, 3 patients required a second dose of dinoprostone gel for cervical ripening. The mean cost of cervical ripening in this group was rupees 277.86 per patient. The difference between mean cost of therapy in the two groups was considerable.

Table 4: Comparison of maternal safety parameters amongst the two groups.

\begin{tabular}{|lll|}
\hline Adverse events & $\begin{array}{l}\text { Dinoprostone } \\
\text { group }(\mathbf{n = 4 5})\end{array}$ & $\begin{array}{l}\text { Foleys } \\
\text { catheter } \\
\text { group }(\mathbf{n}=\mathbf{4 4})\end{array}$ \\
\hline Vomiting & 3 & 0 \\
\hline Chills & 2 & 0 \\
\hline Fever & 3 & 2 \\
\hline Hyperstimulation & 1 & 0 \\
\hline Hypertonous & 1 & 0 \\
\hline $\begin{array}{l}\text { Premature rupture } \\
\text { of membranes }\end{array}$ & 0 & 3 \\
\hline Bleeding & 0 & 2 \\
\hline Total $*$ & 10 & 7 \\
\hline
\end{tabular}

*Difference between total numbers of maternal adverse events in the two groups was not statistically significant. ( $\mathrm{p}$ value by Fishers test $=0.5912$ )

Table 5: Comparison of neonatal safety parameters amongst the two groups.

\begin{tabular}{|lll|}
\hline Adverse events & $\begin{array}{l}\text { Dinoprostone } \\
\text { group }(\mathbf{n = 4 5})\end{array}$ & $\begin{array}{l}\text { Foleys catheter } \\
\text { group }(\mathbf{n = 4 4 )}\end{array}$ \\
\hline NICU admission & 2 & 4 \\
\hline $\begin{array}{l}\text { Transient } \\
\text { tachypnea }\end{array}$ & 0 & 1 \\
\hline $\begin{array}{l}\text { Low APGAR } \\
\text { score }\end{array}$ & 1 & 1 \\
\hline Total* & 3 & 6 \\
\hline
\end{tabular}

Difference between total numbers of neonatal adverse events in the two groups was not statistically significant. ( $p$ value by Fishers test $=0.3148$ )

\section{DISCUSSION}

Uterine cervix is composed of smooth muscle and fibroblast cells interspersed between thick bundles of 
collagen, elastin and glycosaminoglycans. ${ }^{9,10}$ Cervical remodelling that occurs throughout pregnancy and especially towards term corresponds to apoptosis of smooth muscle cells, dispersion of collagen bundles due to increased hydration making the cervix softer and ripe. Many methods are available to assess extent of cervical ripening and the most widely used and accurate is Bishops score. This score takes into consideration parameters like cervical dilatation, effacement, consistency, position and head station. Cervix is considered favourable for inducing contractions if Bishops score is more than 5 and unfavourable if score is 5 or less. Thus change in Bishops score was considered as the primary efficacy parameter in this study. In both dinoprostone and Foleys catheter groups the cervical ripening was achieved to a similar extent with mean change in score being 7.2 in dinoprostone group and 6.8 in Foleys catheter group. The difference between these scores was not statistically significant. Other studies have reported average increase in cervical ripening in the Foleys catheter group by 5.1 scores which is lesser than our study. ${ }^{11,12}$ The observed discrepancy may be related to the amount of water used for dilation of catheter, which was only $30 \mathrm{ml}$ in contrast to $60 \mathrm{ml}$ in our study. A randomized controlled trial designed to compare the rates of success with respect to volume of inflation also states that a higher volume of water used to inflate catheter increases the chances of obtaining a favourable cervix. ${ }^{13-}$ 15 Being a mechanical method, Foleys catheter induces cervical ripening by separation of membranes and cervical dilation that leads to secretion of endogenous prostaglandins. Thus the amount of water used to dilate balloon of Foleys catheter plays a very important role in the extent of cervical ripening achieved. Since cervical ripening is forerunner of induction of labour and the success of induction depends on the extent of ripening, secondary efficacy parameters of the study were related to success of labour induction like need for oxytocin augmentation, induction delivery interval, mode of delivery and failure of induction. None these parameters differed significantly in the study groups. Many other studies comparing dinoprostone gel with Foleys catheter have come up with similar results. Although the caesarean section rate was higher in our study compared to the other studies, the indications for caesarean section were similar to other studies. ${ }^{5,15,16}$ Study of maternal outcome parameters to compare safety profile of the drugs showed that a total of 10 adverse events were reported in the dinoprostone group while only 7 adverse events were reported in the Foleys catheter group. Although there was no statistically significant difference in the adverse events reported quantitatively, events like uterine hyper stimulation and hypertonus were reported only in the dinoprostone group while premature rupture of membranes was reported only in Foleys catheter group. ${ }^{17}$ Another study conducted at Rothak also shows that only patients in the dinoprostone group experienced hyperstimulation. ${ }^{[17]}$ Difference in pharmacodynamics of Foleys catheter and PGE2 gel may partly explain the qualitative difference observed in type of adverse events.
Foleys catheter acts by increasing endogenous prostaglandin synthesis and has limited capacity to hyperstimulate the uterus while dinoprostone gel increases the local availability of prostaglandings to a greater extent ultimately culminating in hyperstimulation in a few cases. On the contrary, since Foleys leads to mechanical cervical dilation and partial separation of membranes, premature rupture of membrane was more common in this group. Foetal outcome parameters were also comparable in both groups and no neonatal deaths occurred in this study. Similar results with respect to foetal safety were obtained in other studies comparing dinoprostone with Foleys catheter for cervical ripening. ${ }^{11,18}$ Comparison of cost of incurred in the two groups showed that cost of one prefilled syringe of dinoprostone is 260.50 and Foleys catheter varies from Rs 9 per piece to rupees 260 per piece. The Foleys balloon catheter used for this study costs rupees 55 per piece. Comparison of the cost of cervical ripening showed considerable difference in the mean cost of therapy.

\section{CONCLUSION}

To conclude, efficacy and safety of Foleys catheter as a cervical ripening agent prior to induction of labour is comparable to dinoprostone gel used for the same purpose. Since use of Foleys catheter is advantageous in terms of lack of specific storage conditions and cost of treatment, it could be considered a cost effective alternative for pre induction cervical ripening.

\section{ACKNOWLEDGMENTS}

Authors would like to thank all the patients for their cooperation during the study.

Funding: No funding sources Conflict of interest: None declared

Ethical approval: The study was approved by the Institutional Ethics Committee of Government Medical College, Miraj

\section{REFERENCES}

1. Girma W, Tseadu F, Wolde M. Outcome of Induction and Associated Factors among Term and Post-Term Mothers Managed at Jimma University Specialized Hospital: A Two Years' Retrospective Analysis. Ethiopian Journal of Health Sciences. 2016;26(2):121-30.

2. Kehl S, Weiss C, Dammer U, Raabe E, Burghaus S, Heimrich $J$, et al. Induction of labour: change of method and its effects. Geburtshilfe und Frauenheilkunde. 2015 Mar;75(03):238-43.

3. Tsikouras P, Koukouli Z, Manav B, Soilemetzidis M, Liberis A, Csorba R, et al. Induction of Labor in Post-Term Nulliparous and Parous Women-Potential Advantages of Misoprostol over Dinoprostone. 
Geburtshilfe und Frauenheilkunde. 2016 Jul;76(07):785-92.

4. ACOG Committee on Practice Bulletins - Obstetrics . Practice Bulletin No 107: Induction of labor. Obstet Gynecol. 2009;114:386-97.

5. Jani PS, Gandhi MR, Thakor N. Efficacy of misoprostol over dinoprostone gel and Foley's catheter as a cervical ripening agent. Int $\mathrm{J}$ Med Sci Public Health. 2015;4:888-92.

6. Alaparthi PN, Aravinda K. Comparative study of the induction of labour with intravaginal misoprostol and intracervical dinoprostone gel. J. Evolution Med. Dent. Sci. 2016;5(21):1120-3.

7. Jozwiak M1, Bloemenkamp KW, Kelly AJ, Mol BW, Irion O, Boulvain M. Mechanical methods for induction of labour. Cochrane Database Syst Rev. 2012 Mar 14;(3):CD001233.

8. Rath W, Kehl S. The Renaissance of Transcervical Balloon Catheters for Cervical Ripening and Labour Induction. Geburtshilfe und Frauenheilkunde. 2015;75(11):1130-9.

9. Myers KM, Feltovich H, Mazza E, Vink J, Bajka M, Wapner RJ, et al. The mechanical role of the cervix in pregnancy. Journal of biomechanics. 2015 Jun 25;48(9):1511-23.

10. Mahendroo M. Cervical remodeling in term and preterm birth: insights from an animal model. Reproduction. 2012 Apr;143(4):429-38.

11. Alam A, Ahmed EA. A comparative study of intracervical foley's catheter and PGE2 gel for preinduction cervical ripening. Int J Reprod Contracept Obstet Gynecol. 2016;5:2644-7.

12. Baloch R, Muhabat Q, Waheed F, Ahmed. Comparative Effects of Ballooning Intracervical Catheter and Prostaglandin Pessary on Cervical Ripening. Open Journal of Obstetrics and Gynecology. 2016;6:525-33.
13. Delaney S, Shaffer BL, Cheng YW, Vargas J, Sparks TN, Paul K, et al. Labor induction with a Foley balloon inflated to $30 \mathrm{~mL}$ compared with $60 \mathrm{~mL}$ : a randomized controlled trial. Obstetrics \& Gynecology. 2010 Jun 1;115(6):1239-45.

14. Kashanian M, Nazemi M, Malakzadegan A. Comparison of $30-\mathrm{mL}$ and $80-\mathrm{mL}$ Foley catheter balloons and oxytocin for preinduction cervical ripening. Int J Gynaecol Obstet. 2009 May;105(2):174-5.

15. Wijepala J, Najimudeen M. Comparison of $30 \mathrm{ml}$ and $60 \mathrm{ml}$ Foley Catheter for cervical ripening. European Scientific Journal, ESJ. 2013 Feb 28;9(6).

16. Jenkins A, Sendhil CA, Ghose S. Comparison of the efficacy of extra amniotic Foley catheter, intravaginal prostaglandin $\mathrm{E} 1$ tablet and intracervical prostaglandin E2 gel for pre induction cervical ripening: a randomized comparative study. Int $\mathbf{J}$ Reprod Contracept Obstet Gynecol. 2016;5:3902-8.

17. Dahiya K, Malik K, Dahiya A, Nanda S. Comparison of the Efficacy of Foley Catheter Balloon with Dinoprostone Gel for Cervical Ripening at Term International Journal of Clinical Medicine. 2012;3:527-31.

18. Li Y, He Z, Song L, Zhang J, Wang J, Cheng J. Foley catheter balloon versus prostaglandins for cervical ripening and labor induction: a systematic review and meta-analysis Int J Clin Exp Med. 2016;9(4):757384.

Cite this article as: Murthy BK, Murthy MB, Teje RS. Intracervical foleys catheter: Can it serve as an alternative to standard pharmacological method of cervical ripening?. Int J Basic Clin Pharmacol 2017;6:1713-7. 